\title{
플렉서블 $\mathrm{Li} / \mathrm{MnO}_{2}$ 일차전지의 제조공정에 따른 전기적 특성
}

\author{
이미재 ${ }^{\dagger}$ - 채유진 · 김진호 - 황종희 · 박상선* \\ 한국세라믹기술원, *(주)비츠로셀
}

\section{Electrical Characteristics According to the Manufacturing Process of the Flexible $\mathrm{Li} / \mathrm{MnO}_{2}$ Primary Cell}

\author{
Mi-Jai Lee $\dagger$, Yoo-Jin Chae, Jin-Ho Kim, Jong-Hee Hwang and Sang-Sun Park* \\ Korea Institute of Ceramic Engineering \& Technology, *Vitzrocell
}

(2012년 11월 1일 접수 : 2012년 12월 10일 최종수정 : 2012년 12월 12일 채택)

\begin{abstract}
Manganese dioxide $\left(\mathrm{MnO}_{2}\right)$ is one of the most important cathode materials used in both aqueous and non-aqueous batteries. The $\mathrm{MnO}_{2}$ polymorph that is used for lithium primary batteries is synthesized either by electrolytic $\left(\mathrm{EMD}-\mathrm{MnO}_{2}\right)$ or chemical methods $\left(\mathrm{CMD}-\mathrm{MnO}_{2}\right)$. Commonly, electrolytic manganese dioxide (EMD) is used as a cathode mixture material for dry-cell batteries, such as a alkaline batteries, zinc-carbon batteries, rechargeable alkaline batteries, etc. The characteristics of lithium/manganese-dioxide primary cells fabricated with $\mathrm{EMD}-\mathrm{MnO}_{2}$ powders as cathode were compared as a function of the parameters of a manufacturing process. The flexible primary cells were prepared with EMD- $\mathrm{MnO}_{2}$, active carbon, and poly vinylidene fluoride (PVDF) binder (10 wt.\%) coated on an Al foil substrate. A cathode sheet with micro-porous showed a higher discharge capacity than a cathode sheet compacted by a press process. As the amount of EMD- $\mathrm{MnO}_{2}$ increased, the electrical conductivity decreased and the electrical capacity increased. The cell subjected to heat-treatment at $200{ }^{\circ} \mathrm{C}$ for $1 \mathrm{hr}$ showed a high discharge capacity. The flexible primary cell made using the optimum conditions showed a capacity and an average voltage of $220 \mathrm{mAh} / \mathrm{g}$ and $2.8 \mathrm{~V}$, respectively, at $437.5 \mu \mathrm{A}$.
\end{abstract}

Key words $\underline{\mathrm{Li} / \mathrm{MnO}_{2}}$, flexible primary cell, RFID, active tag, USN.

\section{1. 서 론}

RFID용 태그에서 요구하는 전지는 박막형의 일차전 지로 태그의 한정된 공간에 장착될 수 있도록 초소형이 면서도 최소 2 년 이상 보관(shelf life)이 보장되어야 한 다. 그러면서도 폐기가 용이하도록 친환경적이어야 하며, 기존의 바코드를 대체하는 관점에서 저가여야 한다. 또 한 USN용 센서 노드는 메모리와 통신 기능까지 갖추고 있으며 대부분 보드타입으로 구성되기 때문에 크기가 크 고 소모전력 또한 태그에 비해 매우 높아, 전지도 $3 \mathrm{~V}$ 급 이상이어야 한다. 이러한 용도에 맞는 태그용 전지 로 제안되고 있는 것으로 박막전지(thin film battery)와 필름전지(film battery)가 있다. 일반적으로 필름형 전지
는 최대 $4.5 \mathrm{mAh} / \mathrm{cm}^{2}$ 의 높은 방전용량을 나타내지만, 장 기저장성능에 취약하며, 태그가 주변 환경을 감지하는 센 서를 장착하는 경우에는 소모전력 및 구동전압이 높아 지게 되어 센서태그를 구동할 수 없는 단점을 가지므로 플럭시블 형태의 박형 전지에 대한 필요성이 대두되고 있다. 플럭시블 형태의 박형 전지의 가장 대표적인 전 지는 $\mathrm{Li} / \mathrm{MnO}_{2}$ 전지로 전압은 보통의 dry 전지의 2 배인 $3 \mathrm{~V}$ 로 specific capacity가 높고, 방전 전압이 안정적이고 신뢰성이 높으며, 자기방전 기간이 3 년 이상으로 길고, 자가방전률이 $\leq 2 \%$ 년으로 낮으며, $-20+60{ }^{\circ} \mathrm{C}$ 의 작동온 도 범위를 가진다. ${ }^{1-4)}$ 또한 사각, 원통 및 코인 등 다양 한 형태의 전지를 필요에 따라 만들 수 있는 장점이 있 다. $\mathrm{Li} / \mathrm{MnO}_{2}$ 전지의 셀 반응은 아래와 같이 음극에서는

\footnotetext{
${ }^{\dagger}$ Corresponding author

E-Mail : im1004@kicet.re.kr (M. -J. Lee, KICET)
}

(C) Materials Research Society of Korea, All rights reserved.

This is an Open-Access article distributed under the terms of the Creative Commons Attribution Non-Commercial License (http://creativecommons.org/licenses/by-nc/3.0) which permits unrestricted non-commercial use, distribution, and reproduction in any medium, provided theoriginal work is properly cited. 
$\mathrm{Li}$ 산화반응이, 양극에서는 $\mathrm{Mn}$ 환원반응이 진행된다.

- Lithium Anode $: \mathrm{Li} \rightarrow \mathrm{Li}^{+}+\mathrm{e}^{-}$

- Manganese dioxide cathode :

$$
\mathrm{Mn}^{\mathrm{IV}} \mathrm{O}_{2}+\mathrm{Li}^{+}+\mathrm{e}^{-} \rightarrow \mathrm{Mn}^{\mathrm{III}} \mathrm{O}_{2}\left(\mathrm{Li}^{+}\right)
$$

$\cdot \mathrm{Li} / \mathrm{MnO}_{2}$ total cell reaction $: \mathrm{Li}+\mathrm{Mn}^{\mathrm{IV}} \mathrm{O}_{2} \rightarrow \mathrm{Mn}^{\mathrm{III}} \mathrm{O}_{2}\left(\mathrm{Li}^{+}\right)$

이 반응에서 가장 중요한 재료는 구조에 따라 다른 전 기용량을 갖는 $\mathrm{MnO}_{2}$ 으로 $\mathrm{Mn}$ 의 원자가에 의해 결정된 다. $\mathrm{Li} / \mathrm{MnO}_{2}$ 계에서 전기화학특성은 $\mathrm{MnO}_{2}$ 의 구조와 화 학적 특성에 많은 영향을 받는데, 부푸는 현상이나 자 기방전 등의 문제도 $\mathrm{MnO}_{2}$ 의 구조에 의한 것이다. 이러 한 다양한 구조적 차이를 갖는 $\mathrm{MnO}_{2}$ 는 결정학적으로 상 당히 많은 동질이상체를 갖는데, $\mathrm{Li}$ 일차전지에 적용 가 능한 것은 $\beta-\mathrm{MnO}_{2}$ (pyrolusite), ramsdellite와 $\gamma-\mathrm{MnO}_{2}$ 3종 류이다. 이 중 전지 재료로 사용될 수 있는 전기화학적 으로 활성인 $\mathrm{EMD}$ 물질은 통상적으로 $\gamma-\mathrm{MnO}_{2}$ 상으로 알려져 있다. ${ }^{5-7)}$

따라서 본 연구에서는 양극활물질로 $\mathrm{EMD}$ 를 선정하여 열처리 조건에 따른 구조와 이에 따른 전기화학적 특성 을 평가하였다. 이때, 신뢰성의 가장 큰 문제점인 화재 지연 효과가 큰 $\mathrm{LiPF} 6$ 를 전해질로 사용하여, 셀의 두께 가 $0.7 \mathrm{~mm}$ 이하의 플렉시블 형태인 전지를 제조하여 구 동전압, 방전용량 등의 전지특성을 평가하였다. 또한 플 렉시블 전지를 제조하기 위한 양극 쉬트 제조 공정인 바 인더, 탈포 조건, 전극활물질의 양 등을 변화시키면서 전 지특성을 평가하였다.

\section{2. 실험 방법}

전극활물질의 경우 출발물질로 사용되는 $\mathrm{MnO}_{2}(\mathrm{EMD}$, Sumitomo), active carbon을 지르코니아 볼을 이용하여
12 시간 동안 건식 혼합하였다. 이때 $\mathrm{MnO}_{2}$ 는 $3500^{\circ} \mathrm{C}$ 까 지는 1 시간 30 분에 승온하여 $350{ }^{\circ} \mathrm{C}$ 에서 8 시간 30 분간 유지한 후 로냉하여 사용하였다. 또한 쉬트 제조를 위 한 바인더는 PVDF(Polyvinylidene fluoride)를 NMP(NMethyl-2-pyrrolidone)에 $10 \mathrm{wt} . \%$ 로 hot plate를 이용하여 stirrer로 계속 혼합하여 용융한 후 사용하였다. 건식으로 혼합한 분말과 바인더의 양을 변화시키면서 고속 혼합 기를 이용하여 30 분간 혼합하여 paste 상태의 slurry를 제 조하였다. 제조한 slurry는 내부의 기포를 제거하기 위해 탈포기를 이용하여 탈포를 진행한 후 doctor blade를 이 용하여 양극집전체인 $\mathrm{Al}$ foil 위에 쉬트를 제조하였다. 제 조한 쉬트는 원하는 두께로 압착기를 이용하여 압착한 후 작두를 이용하여 절단한 후 음극 활물질로 $\mathrm{Li}$, 음극 집전체로는 Ni-cermet을 이용하여 Fig. 1의 순서로 적층 하여 전지를 제조하여 방전 특성을 평가하였다. 이때 전 해액은 $\mathrm{LiPF}_{6} 1 \mathrm{~mol} / \mathrm{EC} / \mathrm{DME}(1.1 \mathrm{vol} \%)$ 를 사용하였고, 세 퍼레이터는 $\mathrm{PE}$ 를 사용하였다. 양극활물질의 결정구조를 알아보기 위해 XRD(Philips사, PW3710)와 미세구조 관 찰을 위해 $\mathrm{SEM}(\mathrm{JEOL}$ 사, JSM-6710F)을 사용하여 측정 하였다.

\section{3. 결과 및 고찰}

\section{1 $\mathrm{EMD}-\mathrm{MnO}_{2}$ 함량에 따른 전기적 특성}

$\mathrm{Li} / \mathrm{MnO}_{2}$ 전지를 제조하기 위해 사용한 $\mathrm{MnO}_{2}$ 의 결정 상을 Fig. 2에 나타내었다. 그림에서 보면 전지를 제조 하기 위해 사용한 $\mathrm{MnO}_{2}$ 는 단일상을 나타내고 있으며, a 축이 $2.786 \AA, b$ 축은 $2.786 \AA$, c축은 $4.412 \AA$ 을 갖는 육 방정계 구조임을 알 수 있다. 이 구조는 산소 음이온이 육방정 밀집구조를 이루면서 망간 양이온이 octahedral site의 $1 / 2$ 를 채우고 있는 구조로 알려져 있다. ${ }^{8}$

전극활물질은 $\mathrm{EMD}-\mathrm{MnO}_{2}$ : active carbon의 무게비로

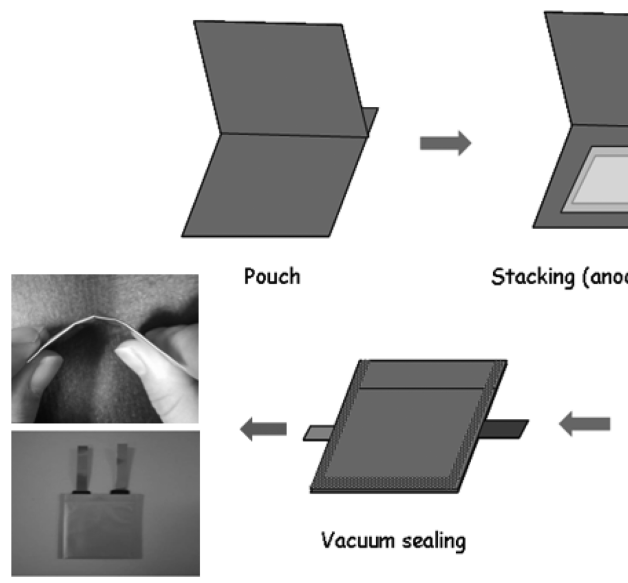

Fig. 1. Process for $\mathrm{Li} / \mathrm{MnO}_{2}$ primary cell manufacture. 


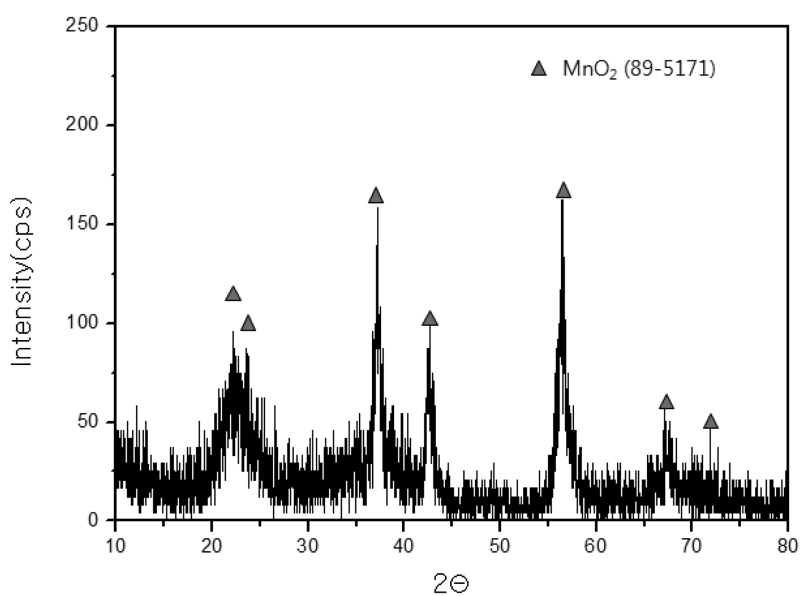

Fig. 2. The crystal structure of EMD- $\mathrm{MnO}_{2}$.

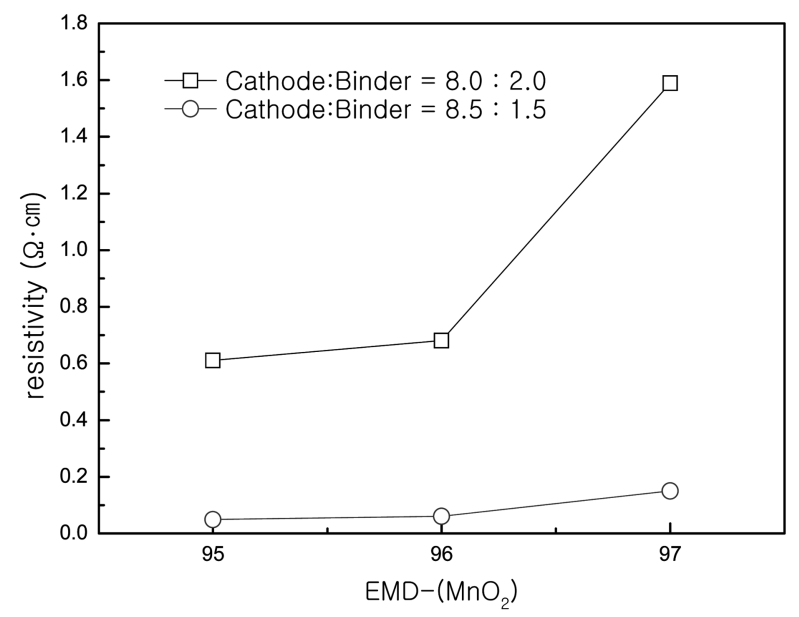

Fig. 3. The resistivity according to amount of EMD- $\mathrm{MnO}_{2}$.

$95: 5,96: 4$ 및 $97: 3$ 로 혼합한 분말과 $\mathrm{PVDF}$ 를 $\mathrm{NMP}$ (N-Methyl-2-pyrrolidone)에 용융하여 $10 \mathrm{wt} \%$ 로 제조한 바인더를 혼합하여 제조한 쉬트의 비저항을 Fig. 3에 나 타내었다. 이때 양극활물질과 바인더의 무게비를 $8: 2$ 와 $8.5: 1.5$ 로 하여 제조하였다. 그림에서 보면 바인더 함량 에 따라 다른 비저항을 나타내고 있는데, 전극활물질과 바인더의 비가 $8.5: 1.5$ 일 때 낮은 비저항을 나타내고 있 었다. 또한 양극활물질 중 $\mathrm{EMD}-\mathrm{MnO}_{2}$ 와 active carbon 첨가량에 따른 비저항의 변화는 $\mathrm{EMD}-\mathrm{MnO}_{2}$ 함량 증가 에 따라 비저항은 증가하고 있었다. 이러한 경우 바인 더의 첨가 경향은 쉬트 내에 들어있는 바인더의 함량을 증가한 경우 건조 후 바인더에 첨가된 $\mathrm{NMP}$ 의 증발량이 많아지고, 이로 인해 입자와 입자 사이에 기공 또는 크 랙이 발생하여 비저항의 증가를 나타낸 것으로 생각되어 진다. 또한, $\mathrm{EMD}-\mathrm{MnO}_{2}$ 첨가량에 따른 결과는 $\mathrm{EMD}-$ $\mathrm{MnO}_{2}$ 에 비해 active carbon의 전기전도도가 낮아 EMD$\mathrm{MnO}_{2}$ 첨가량이 증가하면 높은 비저항을 나타내는 것으 로 생각되어 진다. 따라서 최적의 바인더 함량을 전극

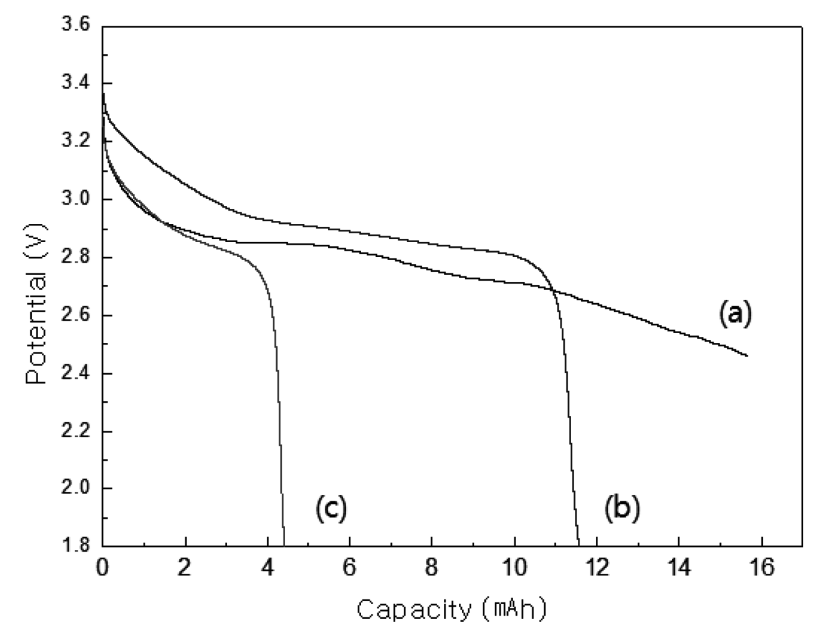

Fig. 4. The discharge characteristics according to amount of EMD$\mathrm{MnO}_{2}$; (a) 97 wt.\%, (b) 96 wt.\% and (c) 95 wt.\%.

활물질과 바인더의 중량비를 $8.5: 1.5$ 로 한 경우로 선정 하여 실험을 진행하였다.

전극활물질과 바인더의 중량비를 $8.5: 1.5$ 로 하고, 전 극활물질인 EMD- $\mathrm{MnO}_{2}$ : active carbon의 무게비를 95 : $5,96: 4$ 및 $97: 3$ 로 하여 제조한 전지를 $219 \mu \mathrm{A}$ 로 방 전하였을 때의 특성을 Fig. 4에 나타내었다. 그림에서 보 면 $\mathrm{EMD}-\mathrm{MnO}_{2}$ 함량 $96 \mathrm{wt} . \%$ 인 경우 가장 높은 약 2.9 $\mathrm{V}$ 의 작동전압을 나타내고 있으며, $\mathrm{EMD}-\mathrm{MnO}_{2}$ 첨가량 증 가에 따라 방전 용량은 증가하고 있는 것을 볼 수 있 다. 그러나, EMD- $\mathrm{MnO}_{2}$ : active carbon의 무게비가 97 : 3 인 경우 일정한 사용 전압을 나타내지 못하고, 계속 감 소하는 그래프를 나타내고 있는 것을 볼 수 있다. 이러 한 사용전압의 감소 현상은 일정양 이상의 $\mathrm{EMD}-\mathrm{MnO}_{2}$ 첨가 시 전극 내부의 활성분극으로 인한 저항이 커져 나 타나는 것으로 예상할 수 있다. 따라서, $\mathrm{EMD}-\mathrm{MnO}_{2}$ 과 active carbon의 무게비는 96:4일 때 최적을 결과를 나 타내는 것으로 보인다.

\section{2 압착공정에 따른 특성}

EMD- $\mathrm{MnO}_{2}$ 과 active carbon의 무게비를 $96: 4$ 로 혼합 후 6시간 동안 충분히 탈포하여 제조한 쉬트의 압착 전 후의 미세구조를 Fig. 5 에 나타내었다. 그림에서 보면 압 착 전의 제조한 쉬트 표면은 거친 표면으로, 많은 미세 기공들이 있는 것을 볼 수 있다. 이에 반해 압착한 쉬 트 표면은 매끄러운 표면을 가지고 있으며, 기공이 바 인더에 의해 모두 채워지고 거의 존재하지 않는 것을 볼 수 있다. 이런 표면의 차이는 전해액이 제조한 양극활 물질 내부로 침투하여 충분히 젖을 수 있는 표면의 차 이를 가져오게 된다.

Fig. 6은 제조한 쉬트를 압착하여 제조한 전지의 압착 전·후 방전특성을 나타낸 것으로, $437.5 \mu \mathrm{A}$ 에서 방전하 


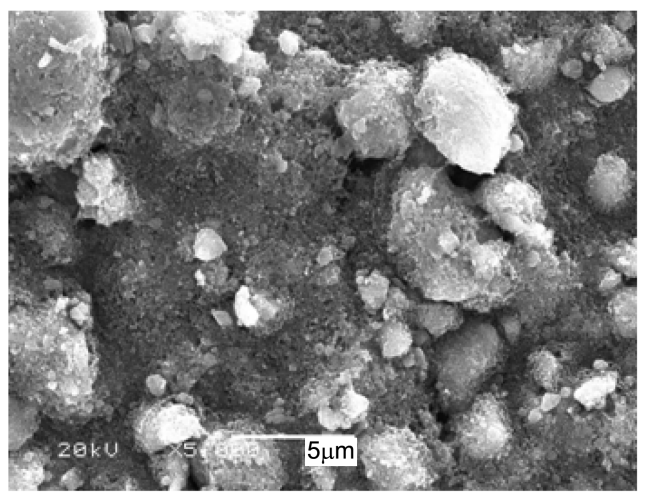

(a)

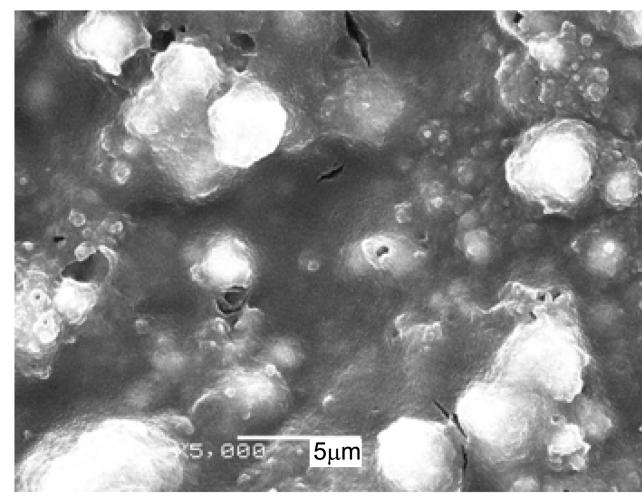

(b)

Fig. 5. The microstructure of cathode sheet surface according to pressing; (a) non pressing and (b) pressing.

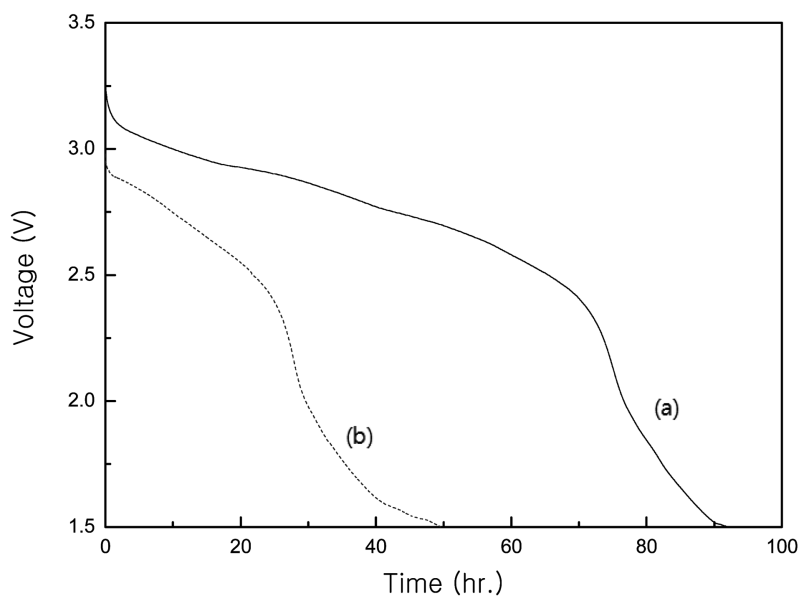

Fig. 6. The discharge characteristics according to pressing; (a) non pressing and (b) pressing.

고, $1.5 \mathrm{~V}$ 에서 cut off한 경우 방전특성을 나타낸 것이 다. 그림에서 보면 압착 전·후의 방전특성은 많은 차이를 나타내는데, 압착 전에 작동전압이 $3.3 \mathrm{~V}$ 임에 반해, 압착 후에는 $2.9 \mathrm{~V}$ 로 떨어지고 있는 것을 볼 수 있다. 또한 용 량 유지시간에도 많은 차이를 나타내고 있는데, 압착 전 에는 방전시간이 90시간 이상 유지된 반면 압착 후에는 50 시간 정도를 나타내고 있다. 이러한 결과는 앞의 미 세구조와 연관되어 볼 수 있는데, 압착한 경우 압착 전 에 존재하던 미세한 기공들이 사라지고, 이로 인해 전 해액의 침투가 원활하지 못해 낮은 방전특성을 나타내 는 것으로 보인다.

\section{3 열처리 공정에 따른 특성}

EMD- $\mathrm{MnO}_{2}$ 과 active carbon의 무게비를 $96: 4$ 로 혼합 후 6시간 동안 충분히 탈포하여 제조한 쉬트를 $200{ }^{\circ} \mathrm{C}$ 에서 1 시간 열처리한 후 제조한 전지를 $437.5 \mu \mathrm{A}$ 에서 방 전하고, $1.5 \mathrm{~V}$ 에서 cut off한 방전특성을 Fig. 7에 나타 내었다. 그림에서 보면 열처리한 양극 쉬트를 사용하여

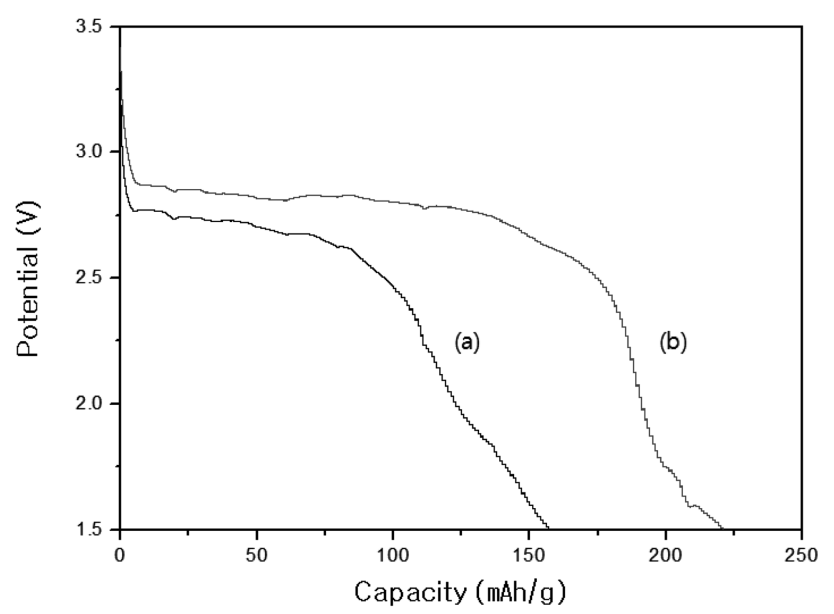

Fig. 7. The discharge characteristics according to heat treatment condition; (a) non heat treatment and (b) heat treatment.

제조한 전지의 경우 열처리하지 않은 쉬트를 사용하여 제조한 전지에 비해 높은 전압과 큰 용량을 나타내고 있 는 것을 확인할 수 있었다. 열처리한 쉬트를 이용하여 제조한 전지의 경우 사용 전압은 $3.4 \mathrm{~V}$ 이었으며, 용량은 $220 \mathrm{mAh} / \mathrm{g}$ 을 나타내고 있었다. 이는 H. Akashi 등이 플 렉시블 일차전지에서 $200 \mu \mathrm{A}$ 에서 방전하여 보고한 사용 전압 $3.2 \mathrm{~V}$, 용량 $16 \mathrm{mAh}$ 보다 높은 값을 나타내었다. ${ }^{9)}$ $\mathrm{Li} / \mathrm{MnO}_{2}$ 전지에 사용되는 $\mathrm{MnO}_{2}$ 가 수분을 함유하는 경 우 스웰링이나 가스 발생과 관계되어 전기화학적 기능에 영향을 미치게 된다. 특히 $\mathrm{MnO}_{2}$ 격자 안에 존재하는 $\mathrm{OH}^{-}$같은 구조수(structural water)의 경우 격자 안에서 $\mathrm{O}^{-2}$ 자리에 $\mathrm{OH}^{-}$가 치환되어 $\mathrm{Mn}^{+4}$ 빈자리 또는 $\mathrm{Mn}^{3+}$ 이 온에 의해 보상된다. 이러한 경우 $\mathrm{Mn}^{+4}$ 이온의 수가 $\mathrm{OH}^{-}$ 와 같은 구조수가 있음으로 해서 감소하게 된다. $\mathrm{MnO}_{2}$ 에서 $\mathrm{Mn}^{+4}$ 이온의 농도 감소는 용량을 감소를 가져오 게 되는데, 보고에 의하면 $4 \mathrm{wt} . \%$ 의 구조수를 함유하게 되면 약 $10 \%$ 의 $\mathrm{MnO}_{2}$ 용량 감소를 가져오고, 약 $8 \mathrm{wt} . \%$ 의 구조를 함유하는 경우에는 약 $20 \%$ 의 용량 감소를 가 
져와 제조한 전지의 성능이 저하되는 문제가 있다. 따 라서 적당한 열처리를 통한 흡착수와 구조수의 제거는 높은 용량을 갖는 전지를 제조하기 위해서는 반드시 필 요한 공정으로 생각되어 진다. ${ }^{10-13)}$

\section{4. 결 론}

플럭시블한 $\mathrm{Li} / \mathrm{MnO}_{2}$ 전지의 제조공정에 따른 전기적 특성을 고찰한 결과 양극활물질과 바인더의 함량이 8.5 : 1.5 인 경우 낮은 비저항을 나타내었고, $\mathrm{EMD}-\mathrm{MnO}_{2}$ 의 양 을 증가시킨 경우 $97 \mathrm{wt} \%$ 에서 비교적 높은 비저항을 나 타내었다. 압착하지 않은 상태로 미세기공을 함유하고 있 는 양극활물질 쉬트가 압착하여 치밀화 된 쉬트에 비해 높은 방전용량을 나타내었으며, $200{ }^{\circ} \mathrm{C}$ 에서 열처리하여 충 분한 수분을 제거한 경우가 높은 방정용량을 나타내었 다. EMD- $\mathrm{MnO}_{2}$ 과 active carbon의 양을 무게비로 $96: 4$ 로 혼합한 분말에, $10 \mathrm{wt} . \% \mathrm{PVDF}$ 를 $5 \mathrm{wt} . \%$ 혼합하여 쉬트를 제조하고, $200{ }^{\circ} \mathrm{C}$ 에서 열처리한 쉬트를 이용하여 제조한 전지의 경우 $437.5 \mu \mathrm{A}$ 에서 방전한 경우 전압은 $3.4 \mathrm{~V}$, 용량은 $220 \mathrm{mAh} / \mathrm{g}$ 를 나타내었다.

\section{감사의 글}

본 연구는 중소기업기술개발 중소기업 기술혁신개발사 업인 '고온, 고출력 웨이퍼형 리튬 일차전지'의 지원으 로 수행되었음을 밝힙니다.

\section{참 고 문 헌}

1. R. M. Dell, Solid State Ionics, 134, 139 (2009).

2. T. J. Lee, T. T. Cheng, H. K. Juang, S. Y. Chen, G. T. K. Fey and H. K. Jaw, J. Power Sources, 44, 709 (1993).

3. T. Ohzuku, M. Kitagawa and T. Hirai, J. Electrochem. Soc., 136, 3169 (1989).

4. Y. Shao-Horn, S. A. Hackney and B. C. Cornilsen, J. Electrochem. Soc., 144, 3147 (1997).

5. Y. Chabre and J. Pannetier, Prog. Solid State Chem., 23, 1 (1995).

6. T. N. Andersen, Progress in Batteries \& Battery Materials, Vol. 11, p. 105-129, eds. D. A. J. Swinkels, Ite-Jec Press, Inc., Ohio, USA (1992).

7. R. Williams, R. Fredlein, G. Lawrance, D. Swinkels, C. Ward, Progress in Batteries \& Battery Materials, Vol. 13, p. 102-112, eds. D. A. J. Swinkels, Ite-Jec Press, Inc., Ohio, USA (1994).

8. P. M. De. Wolff, J. W. Visser, R. Giovanoli and R. Brutsch, Chimia, 32, 257 (1978).

9. H. Akashi, K. Tanaka and K. Sekai, J. Power Sources, 104, 241 (2002).

10. J. A Lee, C. E Newnham, F. S Stone and F. L Tye, J. Colloid Interface Sci., 45, 289 (1973).

11. F. L. Tye, Electrochim. Acta, 21, 415 (1976).

12. P. Reuschi, J. Electrochem. Soc. 131, 2737 (1984).

13. F. Fillaux, C. H. Cachet, H. Ouboumour, J. Tomkinson, C. Levy-Clement and L. T. Yu, J. Electrochem. Soc., 140, 585 (1993). 